УДК 616.366-002-07-089

DOI 10.11603/2414-4533.2016.3.6795

๑ Ю. С. СЕМЕНЮК

К3 “Рівненська обласна клінічна лікарня" Рівненської обласної ради, Центр лапароскопічних і малоінвазивних хірургічних втручань під контролем ендоскопії та сонограсрії імені Ю. Семенюка ${ }^{1}$

ДВНЗ “Тернопільський державний медичний університет імені І. Я. Горбачевського”2

\title{
Діагностично-лікувальний алгоритм при гострому холециститі
}

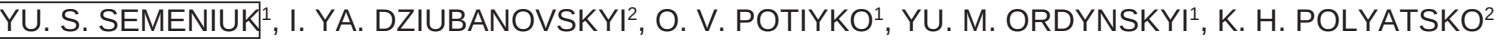 \\ "Rivne Regional Clinical Hospital" of Rivne Regional Coluncil, Yu. Semeniuk Center for Laparoscopic Surgery and Minimally Invasive Con- \\ trolled Endoscopy and Sonography ${ }^{1}$ \\ I. Horbachevsky Ternopil State Medical University²
}

\section{DIAGNOSTIC AND THERAPEUTIC ALGORITHM AT ACUTE CHOLECYSTITIS}

\begin{abstract}
На основі аналізу виконаних у Центрі лапароскопічних і малоінвазивних хірургічних втручань під контролем ендоскопії та сонографії імені ю. Семенюка 12432 лапароскопічних холецистектомій за період 1997-2016 рр. вивчено ускладнення, які виникають під час здійснення лапароскопічних операцій у хворих із гострим деструктивним холециститом, обгрунтовано застосування діагностично-лікувального алгоритму при даній патології, вдосконалено технічні підходи до виконання лапароскопічної холецистектомії, що в сукупності дозволило розширити показання до лапароскопічної холецистектомії у хворих із гострим деструктивним холециститом та його ускладненнями.

Based on the analysis of 12.432 laparoscopic cholecystectomy for the period 1997-2016 years performed at the Center for laparoscopic and Minimally Invasive Surgery Yu. Semeniuk there were studied complications that may arise during laparoscopic surgery in patients with acute destructive cholecystitis, justified the use of diagnostic and therapeutic algorithm in this condition, improved technical approaches to perform laparoscopic cholecystectomy, which together allow expanding the indications for laparoscopic cholecystectomy in patients with acute destructive cholecystitis and its complications.
\end{abstract}

Постановка проблеми і аналіз останніх досліджень та публікацій. Частота захворювання на ЖКХ зустрічається в 10-15 \% дорослого населення [1, 5]. 3 кожним роком все більше уваги приділяється раціональному використанню ліжкового фонду, щоб, у свою чергу, знизити рівень економічних затрат на діагностику та лікування пацієнтів. На даний час ні в кого не виникає сумнівів, щодо твердження, що лапароскопічна холецистектомія - “золотий стандарт” хірургічного лікування жовчнокам'яної хвороби. Слід зазначити, що якщо стосовно хронічного холециститу вже сформувалася чітка думка щодо більшості питань, то при ускладненнях жовчнокам'яної хвороби, таких як гострий холецистит, холедохолітіаз, немає ще повної ясності $[1,2,3]$. Застосувавши лапароскопічну методику для операцій з приводу гострого холециститу, хірурги зіткнулися з цілим рядом технічних ускладнень. Однак переваги малоінвазивної радикальної операції більше, ніж недоліків, і з накопиченням досвіду у значної більшості таких хворих операцію вдається виконати лапароскопічним способом. Протипоказання до лапароскопічної холецистектомії суттєво змінювались у міру впровадження методу. Більшість протипоказань, сформульованих на початкових стадіях, перестали бути основними.

Доцільність активної хірургічної тактики у хворих на гострий холецистит зумовлена тим, що морфологічні зміни в жовчному міхурі, які виникають на фоні внутрішньоміхурової гіпертензії й зумовлені запальним процесом, безслідно не зникають і призводять до розвитку численних інтра- та екстраміхурових ускладнень. Позірне покращення стану хворого при інфузійній і антибактеріальній терапії найчастіше є суб'єктивно “удаваним”, а тому не завжди об'єктивно відображає зворотність запально-деструктивного процесу в жовчному міхурі [4].

Питання терміновості виконання операції при гострому холециститі в різних вікових групах різними хірургічними школами трактується неоднозначно [5, 6].

Мета роботи: проаналізувати власний досвід лікування хворих із гострим холециститом та ускладненнями ЖКХ за період 1997-2016 рр. На основі отриманих результатів розробити діагностично-лікувальний алгоритм при гострому 
холециститі та його ускладненнях, розширити діапазон використання міні-інвазивних технологій шляхом удосконалення методики лапароскопічної холецистектомії, обірунтування етапності лікування ускладнень жовчнокам’яної хвороби під час лапароскопічної холецистектомії при гострому холециститі та профілактики ускладнень у післяопераційному періоді.
Матеріали і методи. За період 1997-2016 pp. у Центрі лапароскопічних і малоінвазивних хірургічних втручань під контролем ендоскопії та сонографії імені Ю. Семенюка (ЦЛМІХВ) з приводу ЖКХ виконано 12432 лапароскопічних холецистектомії, при цьому з них 2231 при гострому холециститі. У всіх спостереженнях діагноз підтверджено морфологічно (табл. 1).

Таблиця 1. Результати гістологічного дослідження жовчних міхурів

\begin{tabular}{||l|c|c||}
\hline \multicolumn{1}{|c|}{ Морфологічний діагноз } & Кількість досліджень & \multicolumn{1}{c||}{$\begin{array}{c}17,94 \\
\text { (від всіх досліджень) }\end{array}$} \\
\hline $\begin{array}{l}\text { Гострий калькульозний холецистит } \\
\text { (катаральний, флегмонозний, гангренозний) }\end{array}$ & 2231 & 29,8 (від ГХ) \\
\hline Гострий катаральний калькульозний холецистит & 665 & 49,3 (від ГХ) \\
\hline Гострий флегмонозний калькульозний холецистит & 1099 & 20,9 (від ГХ) \\
\hline Гострий гангренозний калькульозний холецистит & 467 & \\
\hline
\end{tabular}

У передопераційному періоді здійснювали лабораторні дослідження, які включали загальний аналіз крові, біохімічний аналіз: загальний білірубін та його фракції, АлАТ, АсАТ, лужна фосфатаза, коагулограма. Всім пацієнтам проводили УЗД черевної порожнини. Перед УЗД ставили такі завдання: оцінити зміни розмірів жовчного міхура (збільшення, рубцеве зморщування), його розташування (дно виступає за край печінки, на рівні краю печінки, внутрішньопечінкове розміщення), товщину і стан його стінок, характер вмісту порожнини міхура, положення конкрементів у порожнині міхура і їх рухливість, стан позапечінкових жовчних проток, виявити наявність або відсутність інфільтративних змін в ділянці шийки жовчного міхура, наявність або відсутність біля міхура інфільтратів та рідинних утворів. Крім того, проводили фіброгастродуоденоскопію, електрокардіографію, спірометрію. За показаннями проводили ЕРХПГ, при наявності конкрементів у позапечінкових жовчних ходах виконували ЕПСТ та екстракцію конкрементів.

При визначенні показань і вибору строків операційного втручання у хворих на гострий холецистит оцінювали динаміку (кожні 6-12 год) 12 сонографічних ознак локального запального процесу жовчного міхура і ступінь операційно-анестезіологічного ризику за шкалою S. F. Larsen (1987) та L. Goldman (1995), адаптованою для хворих із гострим холециститом.

Серед оперованих хворих у 316 (2,91 \%) діагностовано холедохолітіаз. У 299 (94,6 \%) пацієнтів холедохолітіаз та механічну жовтяницю ліквідували шляхом проведення трансендоскопічної папілотомії з наступним виконанням ЛХЕ. У 17 (5,4 \%) випадках трансендоскопічну холедохолітоекстракцію проведено після ЛХЕ, причому в 12 хворих інтраопераційно було дреновано холедох за Піковським.
Результати досліджень та їх обговорення.Ретроспективно виконання ЛХЕ в Центрі ми поділили на три періоди: період 1997-2002 рр. - освоєння методики ЛХЕ, 2003-2008 рр. - період розширення діапазону ЛХЕ (збільшення кількості хворих із деструктивними формами ГКХ), 2009-2016 рр. - період вдосконалення ЛХЕ та впровадження власних технічних підходів у хворих з ускладненими формами ЖКХ, розширення можливостей лапароскопії (виконання симультанних операцій).

Кількість прооперованих хворих на ЖКХ, відповідно до періоду госпіталізації, наведено в таблиці 2.

За даними літератури, перехід до лапаротомії (конверсія) - негативний результат ЛХЕ, частота якої за відсутності суворої селекції пацієнтів становить 1,2-6,3 \% [2]. За результатами нашої роботи, в перші 6 років (період освоєння) частота конверсії становила 4,16 \% (24 хворих), в наступний період вона склала 1,38 \% (8 хворих), в останньому періоді було три (0,27 \%) конверсії.

Співвідношення хворих на ГКХ за періодами госпіталізації було 0,96:0,96:1,08. Причому в першому періоді переважали недеструктивні форми ГКХ, що становило 73 \% пацієнтів (вівся селективний відбір пацієнтів до операції за сонографічними даними). У другому періоді співвідношення між недеструктивними та деструктивними формами ГКХ було 37 до 63 \% випадків. У третьому періоді переважали пацієнти з гострим деструктивним калькульозним холециститом (виявлено у 82 \% хворих) та ускладнені форми ЖКХ.

Таблиця 2. Кількість лХЕ відносно періоду госпіталізації

\begin{tabular}{||c|c||}
\hline Періоди госпіталізації & ЛХЕ у хворих із ГКХ \\
\hline 1997-2002 & 576 \\
\hline $2003-2008$ & 577 \\
\hline $2009-2016$ & 1078 \\
\hline
\end{tabular}


Загальна частота післяопераційних ускладнень склала 1,16 \% (126 хворих). Кількість післяопераційних ускладнень у третьому періоді, порівняно з попередніми роками, була найменшою - 0,38 \%. У період 1997-2002 pр. та 2003-2008 рр. післяопераційні ускладнення були, відповідно, 2,19 та $1,08 \%$.

Післяопераційна летальність становила 0,04 \% (4 хворих) та виникла у перші два періоди. Два пацієнти померли від розлитого перитоніту (в одного була жовчотеча $з$ міхурової протоки, в іншого пацієнта виникла перфоративна виразка ДПК), третій пацієнт помер від ТЕЛА, в останнього летальний випадок пов'язаний з прогресуванням ХНН.
Статистично не відрізнялась середня тривалість лікування хворих у трьох періодах, середній термін перебування в стаціонарі становив $(3,67 \pm 0,74)$ дня.

Структуру ускладнень після ЛХЕ в Центрі наведено в таблиці 3. Показник інтраопераційних ускладнень загалом за весь дослідний період становив 4,95 \% (від загальної кількості операційних втручань).

Враховуючи досвід та аналізуючи ускладнення в Центрі, ми використовуємо таку тактику ведення пацієнтів із гострим холециститом та його ускладненнями (схема 1).

Діагностично-лікувальний алгоритм при гострому холециститі.

Таблиця 3. Інтраопераційні ускладнення після ЛXЕ

\begin{tabular}{||l|c|c|c||}
\hline \multicolumn{1}{|c|}{ Вид ускладнень } & \multicolumn{3}{|c||}{ Періоди, n (\%) } \\
\cline { 2 - 4 } & $1997-2002$ pp. & $2003-2008$ pp. & 2009-20016 pp. \\
\hline Внутрішньочеревна кровотеча з ложа печінки & $71(2,2 \%)$ & $46(1,2 \%)$ & $18(0,47 \%)$ \\
\hline Внутрішньочеревна кровотеча з міхурової артерії & $8(0,25 \%)$ & $3(0,08 \%)$ & 0 \\
\hline Пошкодження гепатикохоледоха & $2(0,06 \%)$ & $1(0,03 \%)$ & 0 \\
\hline Пошкодження внутрішніх органів & $5(0,16 \%)$ & $2(0,05 \%)$ & $27(0,7 \%)$ \\
\hline $\begin{array}{l}\text { Ускладнення при евакуації макропрепарата з } \\
\text { черевної порожнини }\end{array}$ & $215(6,7 \%)$ & $143(3,8 \%)$ & \\
\hline \multicolumn{4}{|l|}{} \\
\hline
\end{tabular}

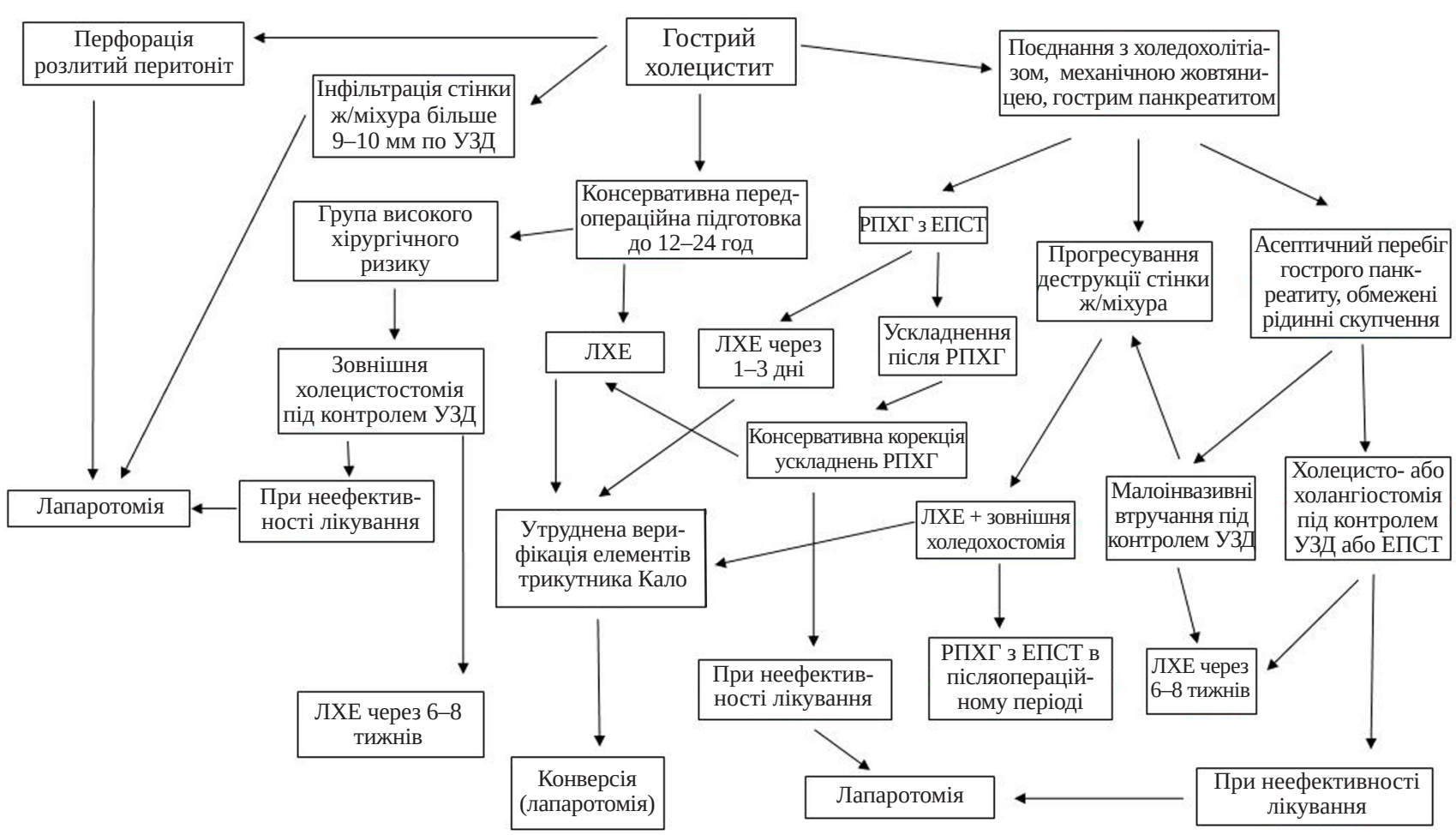

Схема 1. Діагностично-лікувальний алгоритм при гострому холециститі.

Висновки. 1. Основні моменти, що сприяють зменшенню помилок у хірургічному лікуванні ЖКХ при гострому холециститі, такі:

- повноцінний аналіз анамнезу, об’єктивних даних та додаткових методів обстеження;
- корекція супутньої патології в доопераційному періоді;

- УЗД як найбільш інформативний та неінвазивний метод відбору хворих до ЛХЕ;

- проведення УЗД оперуючим хірургом, інтер- 


\section{З ДОСВІДУ РОБОТИ}

претація сонографічних даних та їх узгодження 3 клінічною картиною, що дає можливість проводити більш виважений відбір хворих до ЛХЕ, уникати та прогнозувати інтраопераційні ускладнення при ГКХ;

- рання (своєчасна) операція, до розвитку вторинних ускладнень, повноцінна до- та інтраопераційна ревізія жовчних шляхів, поєднання радикальності операційного втручання 3 його найменшою тривалістю, технічно правильне виконання операції, раціональне ведення післяопераційного періоду;

- вибір методу малоінвазивного хірургічного лікування гострого та хронічного калькульозного холециститу, ускладненого холедохолітіазом, повинен бути диференційованим залежно від бага-

\section{СПИСОК ЛІТЕРАТУРИ}

1. Андрющенко В. П. Поодинокі, численні, поєднані ускладнення гострого холециститу та можливість їх корекції з використанням загальноприйнятих і сучасних хірургічних технологій / В. П. Андрющенко, В. І. Прикупенко, Д. В. Андрющенко // Клін. хірургія. - 2004. - № 4-5. - С. 39.

2. Гончар М. Г. Інтраопераційні ускладнення під час виконання лапароскопічної холецистектомії / М. Г. Гончар, О. М. Глущук // Клін. хірургія. - 2012. - № 2. - С. 39-41.

3. Деякі питання діагностики і лікування гострого холециститу / В. А. Шуляренко, В. А. Шило, 3. 3. Парацій [та ін.] // Збірник наукових праць співробітників НМАПО імені П. Л. Шупика. - 2007. - Вип. 16, кн. 4. - С. 126-130.

4. Дзюбановський І. Я. Обгрунтування активної хірургічної тьох чинників (технічні й ситуативні можливості лапароскопічної холедохолітотомії, характер запального процесу, загальний стан хворого);

- на даний час найбільш поширеним є двохетапний метод - ЕПСТ із наступною ЛХЕ. Показаннями до даного методу є наявність гострого холангіту, гострого біліарного панкреатиту, холедохолітіазу в поєднанні з папілостенозом, защемленого каменя у ВС ДПК, високого операційного ризику.

2. При правильному індивідуальному підборі хворих, виборі методу та об’єму операції завдяки лапароскопії ми досягли не тільки зменшення ризику післяопераційних ускладнень, але й скоротили термін перебування пацієнта в стаціонарі.

тактики у хворих на гострий холецистит літнього та старечого віку / І. Я. Дзюбановський, Л. В. Синоверський, М. С. Гнатюк // Шпитальна хірургія. - 2004. - № 1. - С. 18-24.

5. Вибір тактики лікування при гострому калькульозному холециститі / В. М. Клименко, С. М. Кравченко, С. В. Вдовіло [та ін.] // Шпитальна хірургія. - 2004. - № 6. - С. 79-82. 6. Лікувальна тактика при калькульозному холециститі / Б. О. Мільков, В. В. Білоокий, М. М. Гресько, Д. Б. Домбровський // Шпитальна хірургія. - 2002. - № 3. - С. 14-16.

7. Семенюк Ю. С. Новий спосіб лапароскопічної холецистектомії при гострому холециститі / Ю. С. Семенюк, В. А. Федорук // Вісник Української медичної стоматологічної академії. - 2008. - Т. 8, В. 1-2 (21-22). - С. 116-120.

Отримано 16.05.16 